\title{
Future prospects for ascochyta blight resistance breeding in cool season food legumes
}

\section{Rubiales* and S. Fondevilla}

Consejo Superior de Investigaciones Cientificas, Institute for Sustainable Agriculture, Córdoba, Spain

\section{Edited by:}

David Bryla, United States

Department of Agriculture, USA

\section{Reviewed by:}

Maria Carlota Vaz Patto,

Universidade Nova de Lisboa,

Portugal

Weidong Chen, United States

Department of Agriculture, USA

\section{*Correspondence:}

D. Rubiales, Consejo Superior de Investigaciones Cientificas, Institute for Sustainable Agriculture, Apdo. 4084, 14080 Córdoba, Spain. e-mail: diego.rubiales@ias.csic.es
Legume cultivation is strongly hampered by the occurrence of ascochyta blights. Strategies of control have been developed but only marginal successes achieved. Breeding for disease resistance is regarded the most cost efficient method of control. Significant genetic variation for disease resistance exists in most legume crops with numerous germplasm lines maintained, providing an excellent resource for plant breeders. Fast and reliable screening methods have been adjusted to fulfill breeding program needs. However, the complex inheritance controlled quantitatively by multiple genes, has been difficult to manipulate. Successful application of biotechnology to ascochyta blight resistance breeding in legume crops will facilitate a good biological knowledge both of the crops-pathogen interaction and of the mechanisms underlying resistance. The current focus in applied breeding is leveraging biotechnological tools to develop more and better markers to speed up the delivery of improved cultivars to the farmer. To date, however, progress in marker development and delivery of useful markers has been slow in most legumes. The limited saturation of the genomic regions bearing putative QTLs in legume crops makes difficult to identify the most tightly linked markers and to determine the accurate position of QTLs. The application of next generation sequencing technologies will contribute to the development of new markers and the identification of candidate genes for ascochyta blight resistance.

Keywords: Ascochyta, breeding, legumes, resistance, biotechnology
Cool season food legumes (chickpea, faba bean, lentil, and pea) provide an excellent source of high quality plant protein and have a key role in arable crop rotations reducing the need for fertilizer application and acting as break-crops. However, these crops are affected by a number of foliar and root diseases, being ascochyta blights the most important group of diseases worldwide. Ascochyta blights are incited by different pathogens in the various legumes, namely Ascochyta rabiei (teleomorph Didymella rabiei) in chickpea; $A$. fabae (teleomorph $D$. fabae) in faba bean; A. lentis (teleomorph D. lentis) in lentil; and A. pisi, Phoma medicaginis var. pinodella (previously A. pinodella), and Mycosphaerella pinodes in pea (Tivoli et al., 2006). A number of control strategies have been developed including cultural practices and chemical control (Pande et al., 2005; Davidson and Kimber, 2007; FernándezAparicio et al., 2010; Stoddard et al., 2010). However, only marginal successes have been achieved, most control methods being uneconomical, hard to achieve or resulting in incomplete protection. Breeding for resistance is widely acknowledged as the most economic and environmentally friendly control method. However, resistance breeding is also not an easy task (Muehlbauer and Chen, 2007; Rubiales and Fondevilla, 2010; Sillero et al., 2010). We will review and discuss current achievements in breeding for resistance to ascochyta blights in major cool season food legumes and present future prospects.

Sources of partial resistance have been identified in all of the cool season food legumes and the currently available resistance is being used in breeding programs designed to develop cultivars with improved resistance. There are some recent reviews on breeding methods, screening procedures, the ascochyta diseases, and biology of the pathogens (Pande et al., 2005; Tivoli et al., 2006). Therefore we will concentrate in this review on different aspects of breeding for resistance to ascochyta blight in legumes. The recent developments in understanding the genetics of host resistance will be summarized and the constraints that hampered deployment of resistances discussed. This review will also provide a perspective on the prospects for utilization of novel biotechnological tools for resistance breeding.

Resistance breeding in legume crops has been slow due to the complex nature of resistance and the relatively low investment on genetics, genomics, and biotechnology of legume crops, but also, mainly because of limited knowledge on the biology of the causal agents and on the plant/disease interactions. Comprehensive studies on host status and virulence of the ascochyta blights are often missing, and in most instances there is little agreement on the existence of races and on their distribution. This is a major limitation for any breeding program. Also, available information on levels of resistance and on the responsible mechanisms is often incomplete. Only after significant input to improve existing knowledge on biology of the causal agents as well as on the plant, resistance breeding will be efficiently accelerated.

Resistances identified so far in the various legume crops against the various ascochyta blights provide only incomplete protection. These resistances are mostly polygenic traits controlled by quantitative trait loci (QTLs). However, in some ascochyta-legumes 
interactions both QTLs and major gene have been suggested (Table 1). Molecular markers linked to these genes/QTLs have been reported but practical application of MAS in cool season food legumes has been limited. Although the genomic regions controlling resistance are continuously being saturated with new markers, recombination still occurs between flanking markers and resistance traits hampering an efficient selection. Therefore it is necessary to better define the genomic regions controlling resistance and to increase marker density at these regions in order to identify molecular markers more tightly linked to the genes/QTLs of interest.

The use of the recent biotechnology tools can facilitate both, a better understanding of the resistance mechanism and the development of new molecular markers. Gene expression studies will increase our knowledge on the molecular basis of the resistance and the mechanisms underlying the host-parasite interaction and might represent a source of candidate genes for ascochyta blight resistance. The advent of microarray technology has enabled largescale surveys leading to a more integrated view of gene expression responses. However, transcript analysis using macroarrays or microarrays requires the accumulation of sequence information on the species involved, which is not yet available for cool season food legumes. Nevertheless, the high degree of sequence homology among legume species, especially for expressed sequences, enables cross-species application of macro- and micro-arrays. A microarray containing 32 ESTs derived from a cDNA library obtained from a resistant grass pea accession inoculated with $M$. pinodes was used to identify 16 ESTs differentially expressed in resistance (Skiba et al., 2005). Other microarray consisting on a set of chickpea unigenes, the grass pea ESTs identified by Skiba et al. (2005), and lentil resistance gene analogs (RGAs) was used to study resistance response in chickpea against A. rabiei (Coram and Pang, 2006) allowing identification of 97 differentially expressed genes. This same microarray was also used to identify genes involved in resistance to A. lentis in lentil (Mustafa et al., 2009).

More interestingly, advantage can be taken of the knowledge and tools developed in the model legume Medicago truncatula. In this model several microarray platforms have been developed including an affymetrix system that can identify genes involved in legumes defense against ascochyta blight. Hybridization of $M$. truncatula microarray chips with RNA from related species such as pea is possible allowing a more comprehensive understanding of pea molecular response to M. pinodes (Fondevilla et al., 2011). This approach allowed identification of 346 genes differentially regulated in response to $M$. pinodes in a resistant pea accession including genes involved in cell wall reinforcement, phenylpropanoid and phytoalexins metabolism, pathogenesis-related (PR) proteins, and detoxification processes.

Changes in gene expression, regulated by transcription factors (TFs) underlie many biological processes, including the response against pathogens. For example, the putative transcription factor PsDof1 has been suggested as a candidate gene for a QTL involved in resistance to $M$. pinodes in pea (Prioul-Gervais et al., 2007). TFs are usually expressed at low levels, and are therefore difficult to identify by low sensitive techniques such as microarrays, but can be efficiently quantitatively assessed by quantitative RT-PCR (Czechowski et al., 2004). A library containing primers suitable for the amplification of more than 1100 M. truncatula TFs by quantitative PCR has recently been developed at the Max-Planck Institute of Molecular Plant Physiology (Potsdam, Germany) and could be used to quantify transcripts of these TFs in the interactions Medicago-M. pinodes by real-time RT-PCR as has already been used to study TF expression profiling of the interactions of M. truncatula with Erysiphe pisi (Curto et al., 2007).

MicroRNAs (miRNA) can be used in addition to the TF profiling to investigate the post-transcriptional regulation of genes complementing previous knowledge on differential gene expression in M. truncatula in response to $M$. pinodes. A number of miRNAs have already been described in other plant species having biotic or abiotic stress-inducible homologs that can be selected to analyze their expression in cool season legumes systems (Trindade et al., 2010).

Microarrays, TF platform and miRNA analysis are powerful tools for expression studies. However, these techniques demand previous sequence information knowledge, being limited to known genes. As a consequence, genes specifically involved in a specific ascochyta-legume interaction may not be detected. This limitation can be circumvent by the use of non-targeted techniques such as suppression subtractive hybridization cDNA library (SSH) or CDNA-AFLP that do not require knowledge of sequence data, being an excellent tool to identify novel genes in species such as legumes with limited available genomics sequences. cDNAAFLP is a highly reproducible differential display method based on restriction enzymes digestions and selective amplifications under high stringent conditions that facilitates the identification of genes specifically expressed in a given situation. By SSH cDNA libraries enriched for genes differentially regulated between two situations are obtained. The cDNA-AFLP technique has already been applied to chickpea to identify candidate genes for resistance to A. rabiei (Cho et al., 2005) but have not yet been reported in other legumes.

More powerful transcriptomic techniques are emerging thanks to the next generation sequencing (NGS) technologies. These techniques are enabling the rapid sequencing of millions of sequences at a relative low cost comparing to Sanger Sequencing technology. The called "RNA-seq" technique takes advantage of NGS and are based in sequencing the transcriptome in two different situations and comparing the number of times that a gene is present in these two transcriptomes as an estimation of the level of expression of this gene. One of these derived techniques is called SuperSAGE (Matsumura et al., 2010) that has already been used in chickpea to identify genes involved in different abiotic stresses (Molina et al., 2011) and is currently being used to identify genes involved in ascochyta resistance (Kahl et al., 2011).

Next generation sequencing also allow the "novo" sequencing of the genome or transcriptome of a given organism. The still high cost of these techniques is slowing the generation of a reference genome/transcriptome for legumes species. However, a transcriptome of pea has recently been published (Franssen et al., 2011) and some projects are in progress to sequence the genome of chickpea and pea. Hopefully the improvement of sequencing technologies and the reduction of their cost will make possible the sequencing of all legumes species in a near future. The sequencing of the genomes/transcriptome of legumes will represent a great advance in MAS as it will allow discovering new genes, the massive 
Table 1 | Mode of inheritance of resistance to ascochyta blight in legumes.

\begin{tabular}{llll}
\hline Pathogen & Host & Mode of inheritance & Reference \\
\hline A. pisi & Pea & $\begin{array}{l}\text { A major gene modified by } \\
\text { minor genes or QTLs }\end{array}$ & Darby et al. (1985), Dirlewanger et al. (1994) \\
M. pinodes & Pea & $\begin{array}{l}\text { Major genes } \\
\text { OTLs }\end{array}$ & $\begin{array}{l}\text { Clulow et al. (1991), Timmerman-Vaughan et al. (2002), } \\
\text { Tar'an et al. (2003), Prioul et al. (2004), Fondevilla et al. (2008) }\end{array}$ \\
A. lentis & Lentis & Major dominant gene & Ford et al. (1999) \\
& & Major recessive gene & Chowdhury et al. (2001) \\
& OTLs & Rubeena et al. (2006) \\
A. rabiei & Chickpea & Major genes & Singh and Reddy (1993), Collard et al. (2001), Chen et al. (2004) \\
& & OTLs & Santra et al. (2000), Tekeoglu et al. (2002), Collard et al. (2003), Rakshit et al. (2003), \\
& & Udupa and Baum (2003), Cho et al. (2004), Iruela et al. (2006) \\
A. fabae & Faba bean & Major genes & Rashid et al. (1991), Kohpina et al. (2000), Kharrat et al. (2006)
\end{tabular}

identification of new markers as SNPs or SSR, the identifications of miRNA, etc.

Transcriptional profiling does not always reflect resistant phenotypes due to post-transcriptional regulation. Proteomic approaches can be used to characterize proteins differentially expressed in the defense response. Proteins differentially expressed in pea/M. pinodes interaction have been identified by MALDITOF/TOF or ESI-Q-Trap (Castillejo et al., 2010). Secondgeneration proteomic techniques such as two-dimensional differential in gel electrophoresis (2D DIGE) can be used for comparative studies. A technology based in stable isotope labeling called iTRAQ can be used to identify posttranslational modifications (PTM) of proteins, such as phosphorylation, S-nitrosylation, and nitration (Kersten et al., 2006; Forrester et al., 2009).

Transcriptomic and proteomic data are important steps in deciphering a complex biological process, but these techniques are still insufficient to understand biological processes fully since most of them are ultimately mediated by cell metabolites, so metabolomic studies are also needed. Although large-scale, comprehensive metabolomic studies are difficult, a number of targeted analyses can be performed to assess the involvement of subsets of metabolites in various stresses (Allwood et al., 2010).

The combined results obtained through the various above described technologies will serve to increase our knowledge about ascochyta-legumes interaction and could also be a source of candidate genes involved in the resistance to ascochyta blight. To discern which candidate genes could be more likely involved in the control of the resistance, these candidate genes could be mapped in populations where QTLs for ascochyta blight have been identified. Those genes located into a QTL will be more likely involved in the control of resistance.

Mapping of genes involved in defense in maps containing QTLs for resistance to ascochyta blight have resulted in the identification of candidate genes for resistance to ascochyta blight. This approach has revealed the co-localization of QTLs for resistance to $M$. pinodes and RGAs, the putative transcription factor PsDof1 and the pea defensin DRR230-b (Timmerman-Vaughan et al., 2002; Prioul-Gervais et al., 2007). Genes involved in defense co-localizing with resistance QTLs have also been reported in the case of A. rabiei-chickpea. Those included RGAs, catalase, and ribonuclease T2 (Winter et al., 2000; Huettel et al., 2002; Flandez-Galvez et al., 2003; Cho et al., 2004).

Other approaches to identify the genes included in QTLs for ascochyta blight have been attempted. Iruela et al. (2009) used a genome walking method to sequence flanking regions of a sequence characterized amplified region (SCAR) marker linked to a QTL for resistance to A. rabiei. They concluded that this region was a putative retrotransposon fragment and no genes clearly related to resistance were identified. Comparative mapping with M. truncatula have also been attempted to identify candidate genes located into resistance QTLs. As a first step to identify such genes Rajesh et al. (2008) identified a M. truncatula BAC clone syntenic to a chickpea BAC clone containing a molecular marker associated with a QTL for resistance to $A$. rabiei. The synteny between M. truncatula and other legumes has been successfully used also in pea to identify the gene sequence that corresponds to the gene SYM2 involved in symbiosis (Gualtieri et al., 2002).

Although some candidates genes have been postulated, functional analysis are still lacking in most instances. The ability to knockout genes or suppress their expression are powerful methods to determine the function of a gene. This can be done by anti-sense RNA suppression, targeted gene replacement, insertional mutagenesis, gene silencing, and targeted-induced local lesion in genome (TILLING) approaches. TILLING platforms are available for pea (Dalmais et al., 2008), M. truncatula, and L. japonicus (Perry et al., 2003). These platforms consist in populations of chemically mutagenized plants. Point mutations in specific genes can be detected using mismatch specific endonucleases. In the case of absent of mutants for any desirable gene in TILLING collections these genes could be silenced using different techniques. Virus induced genes silence (VIGs) have already been successfully used for silencing of several endogenous pea genes (Constantin et al., 2004). It is now possible to transform many grain legumes (Chandra and Pental, 2003; Somers et al., 2003) although in some cases the rate of recovery of transgenic lines is still low. This has facilitated functional studies, but has not resulted in commercial applications due to technical (regeneration recalcitrance of most legumes), social (public concerns), and political (lower rate of investment in legume crops compared to other crops such as rice, wheat, and maize) reasons. 


\section{CONCLUSION}

Though limited in efficacy in many cases, the control methods available today represent a major progress when compared to the lack of any means for the control of these plants one or two decades ago. Crops can be protected by resistance, by selective fungicides, by biocontrol agents, and by cultural methods that did not existed before.

The current focus in applied breeding is leveraging biotechnological tools to develop more and better markers to allow marker assisted selection with the hope that this will speed up the delivery of improved cultivars to the farmer. To date, however, progress in marker development and delivery of useful markers has been

\section{REFERENCES}

Allwood, J. W., Clarke, A., Goodacre, R., and Mur, L. A. J. (2010). Dual metabolomics: a novel approach to understanding plant-pathogen interactions. Phytochemistry 71, 590-597.

Avila, C. M., Satovic, Z., Sillero, J. C., Rubiales, D., Moreno, M. T., and Torres, A. M. (2004). Isolate and organspecific QTLs for ascochyta blight resistance in faba bean. Theor. Appl. Genet. 108, 1071-1078.

Castillejo, M. A., Curto, M., Fondevilla, S., Rubiales, D., and Jorrín, J. V. (2010). Two-dimensional electrophoresis based proteomic analysis of the pea (Pisum sativum) in response to Mycosphaerella pinodes. J. Agric. Food Chem. 58, 12822-12832.

Chandra, A., and Pental, D. (2003). Regeneration and genetic transformation of grain legumes: an overview. Curr. Sci. 84, 381-387.

Chen, W., Coyne, C. J., Peever, T. L., and Muehlbauer, F. J. (2004). Characterization of chickpea differentials for pathogenicity assay of ascochyta blight and identification of chickpea accessions resistant to Didymella rabiei. Plant Pathol. 53, 759-769.

Cho, S., Chen, W., and Muehlbauer, F. J. (2004). Pathotype-specific genetic factors in chickpea (Cicer arietinum L.) for quantitative resistance to ascochyta blight. Theor. Appl. Genet. 109, 733-739.

Cho, S., Chen, W., and Muehlbauer, F. J. (2005). Constitutive expression of the Flavanone 3-hydroxylase gene related to pathotype-specific ascochyta blight resistance in Cicer arietinum L. Physiol. Mol. Plant Pathol. 67, 100-107.

Chowdhury, M. A., Andrahennadi, C. P., Slinkard, A. E., and Vandenberg, A. (2001). RAPD and SCAR markers for resistance to ascochyta blight in lentil. Euphytica 118, 331-337.

Clulow, S. A., Matthews, P., and Lewis, B. G. (1991). Genetical analysis of resistance to Mycosphaerella pinodes in pea seedlings. Euphytica 58, 183-189.

Collard, B. C. Y., Ades, P. K., Pang, E. C. K., Brouwer, J. B., and Taylor, P. W. J. (2001). Prospecting for sources of resistance to ascochyta blight in wild Cicer species. Australas. Plant Pathol. 30, 271-276

Collard, B. C. Y., Pang, E. C. K., Ades, P. K., and Taylor, P. W. J. (2003). Preliminary investigation of QTLs associated with seedling resistance to ascochyta blight from Cicer echinospermum, a wild relative of chickpea. Theor. Appl. Genet. 107, 719-729.

Constantin, G. D., Krath, B. N., MacFarlane, S. A., Nicolaisen, M., Johansen, I. E., and Lund, O. S. (2004). Virusinduced gene silencing as a tool for functional genomics in a legume species. Plant J. 40, 622-631.

Coram, T. E., and Pang, E. C. K. (2006). Expression profiling of chickpea genes differentially regulated during a resistance response to Ascochyta rabiei. Plant Biotechnol. J. 4, 647-666.

Curto, M., Ferro, N., Krajinski, F., Schlereth, A., Udvardi, M. and Rubiales, D. (2007). "Real-time RT-PCR profiling of transcription factors in Medicago truncatula in response to powdery mildew (Erysiphe pisi)," in Model Legumes Congress, Tunis, 67.

Czechowski, T., Bari, R. P., Stitt, M., Scheible, W., and Udvardi, M. K. (2004). Real-time RT-PCR profiling of over 1400 Arabidopsis transcription factors: unprecedented sensitivity reveals novel rootand shoot-specific genes. Plant J. 38, 366-379.

Dalmais, M., Schmidt, J., Le Signor, C., Moussy, F., Burstin, J., Savois, V., Aubert, G., Brunaud, V., de Oliveira, Y., Guichard, C., Thompson, R., and Bendahmane, A. (2008). UTILLdb, a Pisum sativum in silico forward and reverse genetics tool. Genome Biol.9, R43.

slow in legumes. We are now also facing an accelerated progress in the genomic and biotechnological research, which should soon provide important understanding of some crucial developmental mechanisms in both the parasites and their host plants and will provide candidate genes for resistance to ascochyta blight. The application of NGS technologies will provide a new research framework and molecular tools to be applied in resistance to ascochyta blight in legumes.

\section{ACKNOWLEDGMENTS}

Financial support by projects AGL2008-01239 and AGR-2883 is acknowledged. S. Fondevilla was granted by a JAEdoc contract.

Darby, P., Lewis, B. G., and Matthews, P. (1985). "Inheritance and expression of resistance to Ascochyta pisi," in The Pea Crop, eds P. D. Hebblethwaite M. C. Heath, and T. C. K. Dawkins (London: Butterworths), 231-236.

Davidson, J. A., and Kimber, R. B. E (2007). Integrated disease management of ascochyta blight in pulse crops. Eur. J. Plant Pathol. 119 99-110.

Dirlewanger, E., Isaac, P., Ranade, S. Belajouza, M., Cousin, R., and Devienne, D. (1994). Restriction fragment length polymorphism analysis of loci associated with disease resistance genes and developmental traits in Pisum sativum L. Theor. Appl. Genet. 88, 17-27.

Fernández-Aparicio, M., Amri, M. Kharrat, M., and Rubiales, D. (2010). Intercropping reduces Mycosphaerella pinodes severity and delays upward progress on the pea plant. Crop Prot. 29, 744-750.

Flandez-Galvez, H., Ford, R., Pang, E. C. K., and Taylor, P. W. J. (2003). An intraspecific linkage map of the chickpea (Cicer arietinum L.) genome based on sequence-tagged microsatellite site and resistance gene analog markers. Theor. Appl. Genet. 106, 1447-1456.

Fondevilla, S., Küster, H., Krajinski, F., Cubero, J. I., and Rubiales, D. (2011). Identification of genes differentially expressed in a resistant reaction to Mycosphaerella pinodes in pea using microarray technology. BMC Genomics 12, 28. doi:10.1186/1471-2164-12-28

Fondevilla, S., Rubiales, D., Zatovic, S. and Torres, A. M. (2008). Mapping of quantitative trait loci for resistance to Mycosphaerella pinodes in Pisum sativum subsp. syriacum. Mol. Breed. 21, 439-454.

Ford, R., Pang, E. C. K., and Taylor, P. W. J. (1999). Genetics of resistance to ascochyta blight (Ascochyta lentis) of lentil and the identification of closely linked RAPD markers. Theor. Appl. Genet. 98, 93-98.

Forrester, M. T., Thompson, J. W., Foster, M. W., Nogueira, L., Moseley, M. A., and Stamler, J. S. (2009). Proteomic analysis of $S$ nitrosylation and denitrosylation by resin-assisted capture. Nat. Biotechnol. 27, 557-559.

Franssen, S. U, Shrestha, R. P., Bräutigam, A., Bornberg-Bauer, E., and Weber, A. P. M. (2011). Comprehensive transcriptome analysis of the highly complex Pisum sativum genome using next generation sequencing. BMC Genomics 12 , 227. doi:10.1186/1471-2164-12-227

Gualtieri, G., Kulikova, O., Limpens, E., Kim, D. J., Cook, D. R., Bisseling, T., and Geurts, R. (2002). Microsynteny between pea and Medicago truncatula in the SYM2 region. Plant Mol. Biol. 50, 225-235.

Huettel, B., Santra, D., Muehlbauer, F. J., and Kahl, G. (2002). Resistance gene analogues of chickpea (Cicer arietinum L.): isolation, genetic mapping and association with a fusarium gene cluster. Theor. Appl. Genet. 105, 479-490.

Iruela, M., Pistón, F., Cubero, J. I., Millán, T., Barro, F., and Gil, J. (2009). The marker SCK13603 associated with resistance to ascochyta blight in chickpea is located in a region of a putative retrotransposon. Plant Cell Rep. 28, 53-60.

Iruela, M., Rubio, J., Barro, F., Cubero, J. I., Millán, T., and Gil, J. (2006). Detection of two QTL for resistance to ascochyta blight in an intraspecific cross of chickpea (Cicer arietinum L.): development of SCAR markers associated to resistance. Theor. Appl. Genet. 112, 278-287.

Kahl, G., Juengling, R., Molina, C., Frank, A., Rotter, B., Winter, P., and Horres, R. (2011). "The battle between legumes and their ascochyta pathogens: the host deep superSAGE transcriptome," in Plant and Animal Genome XIX Conference, San Diego, CA, W360. 
Kersten, B., Agrawal, G. K., Iwahashi, H., and Rakwal, R. (2006). Plant phosphoproteomics: a long road ahead. Proteomics 6, 5517-5528.

Kharrat, M., Le Guen, J., and Tivoli, B. (2006). Genetics of resistance to 3 isolates of Ascochyta fabae on faba bean (Vicia faba L.) in controlled conditions. Euphytica 151, 49-61.

Kohpina, S., Knight, R., and Stoddard, F. L. (2000). Evaluating faba beans for resistance to ascochyta blight using detached organs. Aust. J. Exp. Agric. 40, 707-713.

Matsumura, H., Yoshida, K., Luo, S., Kimura, E., Fujibe, T., Albertyn, Z., Barrero, R., Krüger, D. H., Kahl, G., Schroth, G. P., and Terauchi, R. (2010). High-throughput SuperSAGE for digital gene expression analysis of multiple samples using next generation sequencing. PLoS ONE 5, e12010. doi:10.1371/journal.pone. 0012010

Molina, C., Zaman-Allah, M., Khan, F., Fatnassi, N., Horres, R., Rotter, B., Steinhauer, D., Amenc, L., Drevon, J. J., Winter, P., and Kahl, G. (2011). The salt-responsive transcriptome of chickpea roots and nodules via. deep SuperSAGE. BMC Plant Biol. 11, 31. doi:10.1186/1471-2229-11-31

Muehlbauer, F. J., and Chen, W. (2007). Resistance to ascochyta blights of cool season food legumes. Eur. J. Plant Pathol. 119, 135-141.

Mustafa, B. M., Coram, T. E., Pang, E. C. K., Taylor, P. W. J., and Ford, R. (2009). A cDNA microarray approach to decipher lentil (Lens culinaris) responses to Ascochyta lentis. Australas. Plant Pathol. 38, 617-631.

Pande, S., Siddique, K. H. M., Kishore, G. K., Bayaa, B., Gaur, P. M., Gowda, C. L. L., Bretag, T. W., and Crouch, J. H. (2005). Ascochyta blight of chickpea (Cicer arietinum L.): a review of biology, pathogenicity, and disease management. Aust. J. Agric. Res. 56, 317-332.

Perry, J. A., Wang, T. L., Welham, T. J., Gardner, S., Pike, J. M., Yoshida, S., and Parniske, M. (2003). A TILLING reverse genetics tool and a web-accessible collection of mutants of the legume Lotus japonicus. Plant Physiol. 131, 866-871.

Prioul, S., Frankewitz, A., Deniot, G., Morin, G., and Baranger, A. (2004). Mapping of quantitative trait loci for partial resistance to Mycosphaerella pinodes in pea (Pisum sativum L.) at the seedling and adult plant stages. Theor. Appl. Genet. 108, 1322-1334.

Prioul-Gervais, S., Deniot, G., Receveur, E. M., Frankewitz, A., Fourmann, M., Rameau, C., Pilet-Nayel, M. L., and Baranger, A. (2007). Candidate genes for quantitative resistance to Mycosphaerella pinodes in pea (Pisum sativum L.). Theor. Appl. Genet. 114, 971-984.

Rajesh, P. N., O’Bleness, M., Roe, B. A., and Muehlbauer, F. J. (2008). Analysis of genome organization, composition and microsynteny using $500 \mathrm{~kb}$ BAC sequences in chickpea. Theor. Appl. Genet. 117, 449-458.

Rakshit, S., Winter, P., Tekeoglu, M., Juarez Muñoz, J., Pfaff, T., BenkoIseppon, A. M., Muehlbauer, F. J., and Kahl, G. (2003). DAF marker tightly linked to a major locus for ascochyta blight resistance in chickpea (Cicer arietinum L.). Euphytica 132, 23-30.

Rashid, K. Y., Bernier, C. C., and Conner, R. L. (1991). Genetics of resistance in faba bean inbred lines to five isolates of Ascochyta fabae. Can. J. Plant Pathol. 13, 218-225.

Román, B., Satovic, Z., Avila, C. M., Rubiales, D., Moreno, M. T., and Torres, A. M. (2003). Locating genes associated with Ascochyta fabae resistance in Vicia faba L. Aust. J. Agric. Res. 54, 85-90.

Rubeena, T., Taylor, P. W. J., Ades, P. K., and Ford, R. (2006). QTL mapping of resistance in lentil (Lens culinaris ssp. culinaris) to ascochyta blight (Ascochyta lentis). Plant Breed. 125, 506-512.

Rubiales, D., and Fondevilla, S. (2010). Resistance of cool season food legumes to ascochyta blight. Field Veg. Crop Res. 47, 439-442.

Santra, D. K., Tekeoglu, M., Ratnaparkhe, M., Kaiser, W. J., and Muehlbauer, F. J. (2000). Identification and mapping of QTLs conferring resistance to ascochyta blight in chickpea. Crop Sci. 40, 1606-1612.

Sillero, J. C., Villegas-Fernández, A M., Thomas, J., Rojas-Molina, M. M., Emeran, A. A., FernándezAparicio, M., and Rubiales, D. (2010). Faba bean breeding for disease resistance. Field Crops Res. 115, 297-307.

Singh, K. B., and Reddy, M. V. (1993). Resistance to 6 races of Ascochyta rabiei in the world germplasm collection of chickpea. Crop Sci. 33 186-189.

Skiba, B., Ford, R., and Pang, E. C. K. (2005). Construction of a cDNA library of Lathyrus sativus inoculated with Mycosphaerella pinodes and the expression of potential defence-related expressed sequence tags (ESTs). Physiol. Mol. Plant Pathol. 66, 55-67.

Somers, D. A., Samac, D. A., and Olhoft, P. M. (2003). Recent advances in legume transformation. Plant Physiol. 131, 892-899.

Stoddard, F. L., Nicholas, A. H., Rubiales, D., Thomas, J., and Villegas, A. M. (2010). Integrated pest management in faba bean. Field Crops Res. 115, 308-318.

Tar'an, B., Warkentin, T., Somers, D. J. Miranda, D., Vandenburg, A., Blade S., Woods, S., Bing, D., Xue, A., DeKoeyer, D., and Penner, G. (2003). Quantitative trait loci for lodging resistance, plant height and partial resistance to Mycosphaerella blight in field pea (Pisum sativum L.). Theor. Appl. Genet. 107, 1482-1491.

Tekeoglu, M., Rajesh, P. N., and Muehlbauer, F. J. (2002). Integration of sequence tagged microsatellite sites to the chickpea genetic map. Theor. Appl. Genet. 105, 847-854.

Timmerman-Vaughan, G. M., Frew, T. J., Russell, A. C., Khan, T., Butler, R., Gilpin, M., Murray, S., and Falloon, K. (2002). QTL mapping of partial resistance to field epidemics of ascochyta blight of pea. Crop Sci. $42,2100-2111$.

Tivoli, B., Baranger, A., Avila, C. M. Banniza, S., Barbetti, M., Chen, W. Davidson, J., Lindeck, K., Kharrat, M., Rubiales, D., Sadiki, M., Sillero, J. C., Sweetingham, M., and
Muehlbauer, F. J. (2006). Screening techniques and sources of resistance to foliar diseases caused by major necrotrophic fungi in grain legumes. Euphytica 147, 223-253.

Trindade, I., Capitão, C., Dalmay, T., Fevereiro, M., and Santos, D. (2010). miR398 and miR408 are up-regulated in response to water deficit in M. truncatula. Planta 231, 705-716.

Udupa, S. M., and Baum, M. (2003). Genetic dissection of pathotype specific resistance to ascochyta blight resistance in chickpea (Cicer arietinum L.) using microsatellite markers. Theor. Appl. Genet. 106, 1196-1202.

Winter, P., Benko-Iseppon, A. M., Huttel, B., Ratnaparkhe, M., Tullu, A. Sonnante, G., Pfaff, T., Tekeoglu, M., Santra, D., Sant, V. J., Rajesh, P. N., Kahl, G., and Muehlbauer, F. J. (2000). A linkage map of the chickpea (Cicer arietinum L.) genome based on recombinant inbred lines from a C. arietinum (C. reticulatum cross: localization of resistance genes for Fusarium wilt races 4 and 5. Theor. Appl. Genet. 101, 1155-1163.

Conflict of Interest Statement: The authors declare that the research was conducted in the absence of any commercial or financial relationships that could be construed as a potential conflict of interest.

Received: 05 October 2011; accepted: 23 January 2012; published online: 07 February 2012.

Citation: Rubiales $D$ and Fondevilla $S$ (2012) Future prospects for ascochyta blight resistance breeding in cool season food legumes. Front. Plant Sci. 3:27. doi: 10.3389/fpls.2012.00027

This article was submitted to Frontiers in Crop Science and Horticulture, a specialty of Frontiers in Plant Science. Copyright (c) 2012 Rubiales and Fondevilla. This is an open-access article distributed under the terms of the Creative Commons Attribution Non Commercial License, which permits noncommercial use, distribution, and reproduction in other forums, provided the original authors and source are credited. 